\title{
Analisis pola konsumsi rumah tangga pekerja wanita di Kota Jambi
}

\section{Inda Pati Sinambela; Zulfanetti; Etik Umiyati}

\author{
Prodi. Ekonomi Pembangunan, Fakultas Ekonomi Dan Bisnis, Universitas Jambi \\ E-mail Korespondensi: zulfanetti@yahoo.com
}

\begin{abstract}
This study aims to determine the expenditure of household consumption of female workers in Jambi City which is influenced by several factors. This research was conducted using a sampling technique that is purposive sampling. The data used in this study were obtained from a questionnaire about household consumption of female workers in Jambi city. The data method analysis used multiple linear regression analysis to determine the effect of wife's income, husband's income, education and the number of family dependents on household consumption of female workers in the city of Jambi. Based on the normality test, the multicollinearity test, and the heteroscedasticity test there were no deviations from the classical assumptions. The results of the research showed that simultaneously the wife's income, husband's income, education and the number of family dependents significantly influence the household consumption of female workers. The partial results showed that the variable of wife's income, husband's income and the number of family dependents have a significant effect, while education has no significant effect on household consumption expenditure of female workers in Jambi City. R-square value of $91.75 \%$, showed that household consumption can be explained by research variables of $91.75 \%$.
\end{abstract}

Keywords: household consumption, wife's income, husband's income, education, number of family, Jambi City

\begin{abstract}
Abstrak
Penelitian ini bertujuan untuk mengetahui pengeluaran konsumsi rumah tangga pekerja wanita di Kota Jambi yang dipengaruhi oleh beberapa faktor. Penelitian ini dilakukan dengan menggunakan teknik pengambilan sampel yaitu purposive sampling. Data yang digunakan dalam penelitian ini diperoleh dari kuesioner tentang konsumsi rumah tangga pekerja wanita di Kota Jambi. Metode analisis data menggunakan analisis regresi linier berganda untuk mengetahui pengaruh pendapatan istri, pendapatan suami, pendidikan dan jumlah tanggungan keluarga terhadap konsumsi rumah tangga pekerja wanita di Kota Jambi. Berdasarkan uji normalitas, uji multikolinieritas, dan uji heteroskedastisitas tidak ditemukan adanya penyimpangan dari asumsi klasik. Hasil penelitian menunjukkan bahwa secara simultan bahwa variabel pendapatan istri, pendapatan suami, pendidikan dan jumlah tanggungan keluarga berpengaruh signifikan terhadap konsumsi rumah tangga pekerja wanita. Hasil secara parsial menunjukkan bahwa variabel pendapatan istri, pendapatan suami dan jumlah tanggungan keluarga berpengaruh signifikan, sedangkan pendidikan tidak berpengaruh signifikan terhadap pengeluaran konsumsi rumah tangga pekerja wanita di Kota Jambi. Nilai R-square sebesar 91,75\%, menunjukkan bahwa konsumsi rumah tangga dapat dijelaskan oleh variabel-variabel penelitian sebesar 91,75\%.
\end{abstract}

Kata Kunci: konsumsi rumah tangga, pendapatan istri, pendapatan suami, pendidikan, jumlah tanggungan keluarga, Kota Jambi. 


\section{PENDAHULUAN}

Pertumbuhan ekonomi modern merupakan pertanda penting di dalam kehidupan perekonomian (Jhingan, 2016). Salah satu faktor penting yang mempengaruhi pertumbuhan ekonomi adalah sumber daya manusia. Sumber daya manusia (human resources) mengandung dua pengertian. Pengertian yang pertama adalah usaha kerja atau jasa yang dapat diberikan oleh seseorang dalam kurun waktu tertentu untuk menghasilkan barang dan jasa, sementara itu pengertian yang kedua adalah sumber daya manusia menyangkut manusia yang mampu bekerja untuk memberikan jasa atau usaha kerja tersebut. Mampu bekerja menegaskan bahwa sumber daya manusia tersebut mampu menghasilkan barang atau jasa untuk memenuhi kebutuhan masyarakat. Dalam meningkatkan pendapatan perkapita, efisiensi dan produktivitas dari sumber daya manusia itu sendiri sangatlah penting. Para ahli ekonomi modern sering menyebut tentang pembentukan modal insani, yaitu "proses peningkatan ilmu pengetahuan, ketrampilan dan kemampuan seluruh penduduk negara yang bersangkutan." Proses yang dimaksud mencakup kesehatan, pendidikan dan pelayanan sosial pada umumnya (Jhingan, 2016). Pada tanggal 6-8 September 2000 diadakan Konferensi Tingkat Tinggi Perserikatan Bangsa-Bangsa (PBB) di New York, Amerika Serikat yang dihadiri oleh kepala negara dan kepala pemerintahan dari negara-negara yang menjadi anggota PBB untuk membentuk suatu kesepakatan demi menciptakan dunia yang lebih sejahtera, adil, serta damai. Kesepakatan ini selanjutnya disebut tujuan pembangunan millennium (Millenium Development Goals/MDG).

Pada tanggal 6-8 September 2000 diadakan Konferensi Tingkat Tinggi Perserikatan Bangsa-Bangsa (PBB) di New York, Amerika Serikat yang dihadiri oleh kepala negara dan kepala pemerintahan dari negara-negara yang menjadi anggota PBB untuk membentuk suatu kesepakatan demi menciptakan dunia yang lebih sejahtera, adil, serta damai. Kesepakatan ini selanjutnya disebut tujuan pembangunan millennium (Millenium Development Goals/MDG). Millenium Development Goals memiliki delapan tujuan yang ingin dicapai, meliputi: a) memberantas kemiskinan dan kelaparan ekstrem, b) mewujudkan pendidikan dasar untuk semua, c) mendorong kesetaraan gender dan pemberdayaan perempuan, d) menurunkan angka kematian anak, e) meningkatkan kesehatan ibu, f) memerangi HIV dan AIDS, malaria serta penyakit lainnya, g) memastikan kelestarian lingkungan, h) mengembangkan kemitraan global untuk pembangunan. (Stalker, 2008). Tujuan ketiga dari Millenium Development Goalsyang mengedepankan kesetaraan gender dan pemberdayaan perempuan membuktikan bahwa ketimpangan gender masih banyak terjadi pada seluruh aspek kehidupan di dunia termasuk Indonesia. Ketimpangan gender sendiri dapat diartikan sebagai suatu kondisi dimana masih terdapat gap antara laki-laki dan perempuan dalam mencapai manfaat hasil pembangunan yang berkaitan dengan kebutuhan dasar manusia seperti memperoleh pekerjaan, kesehatan dan pendidikan. (Sitorus, 2016)

Penelitian McKinsey Global Institute (2012) menyatakan bahwa Indonesia sekarang sedang berada dalam tahapan bonus demografi, dimana keadaan jumlah penduduk usia produktif lebih besar dibandingkan dengan jumlah penduduk usia non produktif. Kondisi demikian, memiliki nilai positif dan keuntungan besar bila dikelola secara profesional.Saat ini, Indonesia sudah mengalami perkembangan pesat dalam mengurangi ketimpangan antar gender dalam bidang pendidikan. Walaupun tingkat partisipasi angkatan kerja wanita masih lebih rendah dari laki-laki, namun peran pemerintah dalam pembangunan harus terus diperhatikan untuk menentukan kualitas hidup generasi mendatang. Semakin majunya peradaban juga berakibat pada tuntutan biaya kehidupan dalam berbagai bidang semakin tinggi. Tidak hanya kaum laki-laki, 
kaum wanita pun ingin ikut mendapatkan pekerjaan yang layak di masa depan. Semakin banyaknya kesempatan yang tersedia mendorong wanita untuk ikut terlibat dalam mewujudkan emansipasi wanita, salah satunya melalui bekerja. Saat ini, dengan adanya kesetaraan gender memberikan kesempatan untuk para wanita bekerja di luar rumah untuk memenuhi kebutuhan hidup baik untuk dirinya sendiri maupun untuk keluarga. (Lestari, 2017)

Kebutuhan adalah segala sesuatu yang dibutuhkan manusia untuk mempertahankan hidup serta untuk memperoleh kesejahteraan dan kenyamanan dalam hidupnya. Kebutuhan manusia sifatnya tidak terbatas dan akan selalu bertambah seiring dengan berjalannya waktu. Seperti yang sudah disinggung sebelumnya; kebutuhan memiliki sifat yang tidak terbatas sementara uang sebagai alat pemuas kebutuhan sifatnya terbatas. Mangkunegara (2005) mengatakan bahwa kebutuhan merupakan fundamental yang mendasari perilaku konsumen. Apabila kita belum mengetahui kebutuhan yang dibutuhkan oleh konsumen maka kita belum dapat memahami perilaku konsumen dan konsumsi rumah tangganya. Konsumsi suatu rumah tangga dibedakan menurut kelompok makanan dan bukan makanan. Perubahan pendapatan seseorang akan berpengaruh pada pergeseran pola konsumsi. Dengan demikian, pola konsumsi dapat dipakai sebagai salah satu alat untuk mengukur tingkat kesejahteraan penduduk, dimana perubahan komposisinya digunakan sebagai petunjuk perubahan tingkat kesejahteraan. Berikut adalah rata-rata konsumsi perkapita kelompok makanan dan non makanan yang dibedakan berdasarkan kabupaten/kota.

Tabel 1.1 Rata-rata konsumsi perkapita sebulan (rupiah) makanan dan non makanan menurut kabupaten/kota Maret 2017

\begin{tabular}{lccc}
\hline Kabupaten/Kota & Makanan & $\begin{array}{c}\text { Bukan } \\
\text { Makanan }\end{array}$ & $\begin{array}{c}\text { Rata-Rata } \\
\text { Konsumsi }\end{array}$ \\
\hline Kerinci & 516.417 & 364.931 & 881.348 \\
Merangin & 564.337 & 397.231 & 961.568 \\
Sarolangun & 514.300 & 446.968 & 961.268 \\
Batang Hari & 478.819 & 311.764 & 790.583 \\
Muaro Jambi & 524.869 & 358.678 & 883.547 \\
Tanjab Timur & 539.528 & 350.885 & 890.413 \\
Tanjab Barat & 461.800 & 329.527 & 791.327 \\
Tebo & 495.338 & 325.127 & 820.466 \\
Bungo & 543.432 & 434.582 & 978.014 \\
Kota Jambi & 616.292 & 696.291 & 1.312 .582 \\
Kota Sungai & & & \\
Penuh & 709.102 & 585.946 & 1.295 .048 \\
\hline
\end{tabular}

Sumber:Analisis Pola Konsumsi Masyarakat Provinsi Jambi 2017

Berdasarkan Tabel 1.1 di atas, Kota Jambi menempati urutan pertama dalam rata-rata konsumsi perkapita menurut kelompok barang makanan dan non makanan selama sebulan. Kota Jambi sebagai ibukota dari Provinsi Jambi merupakan daerah perkotaan dengan kondisi wilayah yang lebih maju dan berkembang dari daerah-daerah lainnya sehingga dalam kondisi wilayah yang seperti ini, tidak mengherankan jika konsumsi rumah tangga di Kota Jambi juga semakin tinggi. Kaum laki-laki pada umumnya mendapat peran dalam hal mencari nafkah. Sebagai pencari nafkah utama dalam keluarga, kaum laki-laki diharapkan mampu bekerja dan mencari uang untuk memenuhi kebutuhan hidup yang setiap waktu semakin bertambah. Sementara itu, 
kaum wanita seringkali diberikan tanggung jawab dalam mengurus rumah tangga, mulai dari mengurus anak, memasak untuk keluarga sampai membersihkan rumah. Kaum lelaki mencari uang melalui pekerjaan yang mereka tekuni untuk kemudian dialokasi oleh kaum perempuan dalam membeli alat pemuas kebutuhan. Namun, dengan kebutuhan yang sifatnya tidak terbatas dan selalu bertambah, tidak mengherankan kaum wanita banyak yang ikut terjun membantu kaum laki-laki dalam hal mencari nafkah.

Tingkat Partisipasi Angkatan Kerja (TPAK) merupakan suatu indikator ketenagakerjaan yang memberikan gambaran tentang penduduk yang aktif secara ekonomi dalam kegiatan sehari-hari merujuk pada suatu waktu dalam periode survei. Tingkat Partisipasi Angkatan Kerja (TPAK) di Kota Jambi Tahun 2017 adalah sebesar 64.06\%, sementara Tingkat Partisipasi Angkatan Kerja Wanita di Kota Jambi Tahun 2017 adalah sebesar 24.26\%. Hal ini berarti, semakin banyak wanita yang terjun ke dalam lapangan kerja baik sektor formal maupun sektor informal dan ikut bersaing bersama laki-laki dalam memperoleh pekerjaan untuk meningkatkan pendapatan rumah tangganya. Sektor formal merupakan sektor dimana seseorang bekerja pada orang lain atau instansi/kantor dan didasarkan atas kontrak kerja yang jelas dan pengupahan yang diberikan secara tetap. Oleh karena itu pekerja sektor formal dapat digolongkan sebagai tenaga kerja yang terampil dan berpendidikan. Sementara itu, sektor informal merupakan sektor di mana seseorang bekerja pada orang lain atau instansi/kantor tanpa adanya ikatan pekerjaan yang terikat. (Nofianti, 2016)

Berdasarkan Analisis Situasi Ketenagakerjaan Provinsi Jambi Tahun 2017 yang dipublikasikan oleh Badan Pusat Statistik (BPS) Provinsi Jambi, persentase penduduk yang bekerja di sektor formal di Kota Jambi sebesar 66,55\% sementara yang bekerja di sektor informal sebesar $33,45 \%$. Tingginya persentase penduduk yang bekerja di sektor formal di Kota Jambi menunjukkan bahwa penduduk yang bekerja di sektor formal cenderung merupakan tenaga kerja yang memiliki tingkat pendidikan, keterampilan, akses ke lembaga keuangan, produktivitas tenaga kerja serta tingkat upah yang relatif lebih tinggi dibandingkan tenaga kerja yang bekerja di sektor informal. Terdapat tiga faktor mengapa titik perhatian tertuju pada masalah wanita itu karena, (1) adanya asumsi bahwa wanita merupakan salah satu sumber daya manusia dalam pembangunan, (2) kuantitas wanita yang besar, lebih dari separuh jumlah penduduk, (3) dari segi kualitas wanita sebagai penerus nilai dan norma-norma yang berlaku bagi generasi penerus. (Tjokrowinoto dalam Indrayati, 2010: 90). Semakin beratnya beban ekonomi keluarga membuat peran wanita dalam menopang perekonomian keluarga juga semakin besar. Pada zaman sekarang ini, sudah banyak wanita yang bekerja bukan hanya dari golongan rendah dan menengah, tetapi juga dari golongan atas apalagi didukung oleh tingkat pendidikan yang tinggi.

Semakin banyaknya wanita yang berpartisipasi dalam pasar kerja akan mempengaruhi pendapatan rumah tangganya. Pendapatan tersebut digunakan untuk memenuhi kebutuhan hidup yang semakin banyak, mulai dari sandang, pangan, papan, kesehatan dan pendidikan, sehingga akan mengubah pola konsumsi dari rumah tangga itu sendiri. Setiadi (2003) menyebutkan bahwa beberapa faktor yang mempengaruhi konsumsi seseorang adalah tingkat pendapatan, tingkat pendidikan, tingkat kebutuhan, kebiasaan masyarakat, harga barang dan mode. Selanjutnya menurut Kotler (2005) menyatakan bahwa terdapat lima faktor yang mempengaruhi perilaku konsumsi, diantaranya adalah faktor kebudayaan, faktor sosial, faktor pribadi dan faktor psikologis. Bagi pekerja berjenis kelamin wanita yang belum berkeluarga, hal ini mungkin tidak menjadi masalah, namun untuk pekerja wanita yang sudah berkeluarga apalagi juga memiliki tanggungan anak, keadaan seperti ini dapat menuntut mereka 
untuk ikut terjun dalam mencari nafkah apalagi diiringi dengan semakin tingginya harga kebutuhan pokok. Semakin banyaknya kebutuhan maka semakin banyak juga tingkat konsumsi suatu rumah tangga tersebut yang mengharuskan wanita turut serta dalam mencari nafkah. Oleh karena itu, berdasarkan uraian latar belakang di atas, penulis tertarik untuk meneliti dan mengkaji mengenai faktor-faktor yang mempengaruhi konsumsi rumah tangga pekerja wanita yang dipengaruhi oleh pendapatan suami, pendapatan istri, tingkat pendidikan dan jumlah anggota keluarga, sehingga judul yang akan peneliti angkat adalah "Analisis Pola Konsumsi Rumah Tangga Pekerja Wanita di Kota Jambi”.

\section{METODE}

\section{Jenis dan Sumber Data}

Jenis data yang digunakan dalam penelitian ini adalah data primer yang langsung diperoleh dari objek penelitian dan dikumpulkan dengan menggunakan kuisioner dari 120 pekerja wanita yang bekerja di lingkungan pemerintah Kota Jambi.

\section{Metode Penarikan Sampel}

Populasi dalam penelitian ini adalah jumlah pekerja wanita yang bekerja di lingkungan pemerintah Kota Jambi yaitu sebanyak 4.430 orang. Penelitian ini menggunakan teknik pengambilan data purposive sampling, dengan menentukan sampel yang akan digunakan dalam penelitian ini dihitung menggunakan Rumus Slovin, sebagai berikut:

$\mathrm{n}=\frac{N}{1+N e^{2}}$

$$
\mathrm{n}=\frac{4.430}{1+4.430(9 \%)^{2}}
$$

$\mathrm{n}=\frac{4.430}{1+4.430(0,0081)}$

$\mathrm{n}=\frac{4.430}{1+35,883}$

$\mathrm{n}=\frac{4.430}{36,883}$

$\mathrm{n}=120$ orang

Dari perhitungan sampel menggunakan Rumus Slovin, maka dengan populasi sebanyak 4.430 orang dengan tingkat kepercayaan $91 \%$ jumlah sampel yang akan diambil adalah sebanyak 120 orang dengan kriteria sampel adalah pekerja wanita yang bekerja di lingkungan pemerintah Kota Jambi yang memiliki suami. Agar data yang dianalisis dapat digunakan secara optimal, maka penarikan sampel adalah sebagai berikut:

$$
\begin{array}{ll}
\text { 1. Tenaga Kesehatan } & =\frac{970}{4430} \times 120=26,27 \text { dibulatkan menjadi } 26 \text { orang. } \\
\text { 2. Sekretariat Kota Jambi } & =\frac{93}{4430} \times 120=2,5 \text { dibulatkan menjadi } 3 \text { orang. } \\
\text { 3. Inspektorat Kota Jambi } & =\frac{27}{4430} \times 120=0,73 \text { dibulatkan menjadi } 1 \text { orang. }
\end{array}
$$


4. Instansi (Badan \& Dinas) $=\frac{643}{4430}$ x $120=17,41$ dibulatkan menjadi 17 orang.

5. Kecamatan $=\frac{79}{4430} \times 120=2,13$ dibulatkan menjadi 2 orang.

6. Kelurahan $=\frac{191}{4430} \times 120=5,17$ dibulatkan menjadi 5 orang.

7. Tenaga Pendidik $=\frac{2427}{4430} \times 120=65,74$ dibulatkan menjadi 66 orang.

\section{Analisis Deskriptif}

Penelitian ini menggunakan alat analisis deskriptif untuk menjawab pertanyaan pada rumusan masalah pertama dan kedua yaitu mengenai profil dan pola konsumsi rumah tangga pekerja wanita di Kota Jambi. Teknik yang digunakan untuk menganalisis data dalam penelitian ini adalah dengan menggunakan distribusi frekuensi.

\section{Analisis Regresi Berganda}

Teknik analisis ini digunakan untuk menjawab pertanyaan pada rumusan masalah ketiga yaitu faktor-faktor apa saja yang mempengaruhi konsumsi rumah tangga pekerja wanita di Kota Jambi. Faktor-faktor yang telah ditetapkan sebelumnya adalah pendapatan istri, pendapatan suami, pendidikan dan jumlah tanggungan keluarga. Adapun model regresi yang digunakan dalam penelitian ini dinyatakan dalam persamaan berikut ini.

$$
\mathrm{Y}=\alpha+\beta 1 \mathrm{X} 1+\beta 2 \mathrm{X} 2+\beta 3 \mathrm{X} 3+\beta 4 \mathrm{X} 4+\mathrm{e}
$$

Dimana, $\mathrm{Y}=$ Konsumsi rumah tangga pekerja wanita (dalam satuan rupiah), a= Konstanta, $\beta 1, \beta 2, \beta 3, \beta 4=$ Koefisien regresi variabel independen, $X 1=$ Pendapatan istri (dalam satuan rupiah), X2 = Pendapatan suami (dalam satuan rupiah), X3 = Pendidikan (dalam satuan tahun sukses), $\mathrm{X} 4=$ Jumlah tanggungan keluarga, $\mathrm{e}=$ Variabel pengganggu.

\section{HASIL DAN PEMBAHASAN}

\section{Analisis Kondisi Sosial Ekonomi Pekerja Wanita di Kota Jambi}

Analisis deskripsi adalah langkah pertama yang perlu dilakukan untuk mengetahui bagaimana gambaran umum data yang telah dikumpulkan dari responden. Distribusi responden dimaksudkan untuk melihat kondisi sosial ekonomi pekerja wanita di Kota Jambi seperti umur, pendidikan, pendapatan pekerja wanita (dalam penelitian ini disebut sebagai pendapatan istri), pendapatan suami, jumlah tanggungan keluarga dan pola konsumsi rumah tangganya, baik pangan dan non pangan. 
Tabel 1.2 Analisis kondisi sosial ekonomi pekerja wanita di Kota Jambi

\begin{tabular}{lccc}
\hline $\begin{array}{c}\text { Kondisi Sosial Ekonomi Pekerja } \\
\text { Wanita }\end{array}$ & $\begin{array}{c}\text { Rata- } \\
\text { rata }\end{array}$ & Maksimum & Minimum \\
\hline Umur & 40 & 55 & 28 \\
Pendidikan & $\mathrm{S} 1$ & $\mathrm{~S} 2$ & SMA \\
Pendapatan Istri & 4.914 .617 & 7.200 .000 & 4.000 .000 \\
Pendapatan Suami & 4.371 .333 & 7.400 .000 & 0 \\
Jumlah Tanggungan Keluarga & 2 & 5 & 0 \\
Konsumsi Pangan & 1.720 .333 & 2.328 .000 & 1.117 .000 \\
Konsumsi Non Pangan & 5.604 .242 & 7.915 .000 & 1.970 .000 \\
\hline Sumber: Data diolah, 2019 & & &
\end{tabular}

Berdasarkan Tabel 1.2, pendapatan istri (pekerja wanita) tertinggi yang diperoleh adalah sebesar Rp 7.200.000 dan yang paling terkecil adalah pendapatan sebesar Rp 4.000.000, sehingga rata-rata pendapatan yang diperoleh adalah sebesar Rp 4.914.617. Sementara itu, pendapatan suami tertinggi yang diperoleh adalah sebesar Rp 7.400.000 dan yang paling terkecil adalah pendapatan sebesar Rp 0 (tidak memiliki pendapatan), sehingga rata-rata pendapatan yang diperoleh adalah sebesar Rp 4.371.333. Selanjutnya, pendidikan paling tinggi pekerja wanita adalah pendidikan formal yang ditempuh selama 18 tahun atau setara dengan S2, sementara yang terendah adalah pendidikan formal yang ditempuh selama 12 tahun atau setara dengan SMA. Selanjutnya, jumlah tanggungan keluarga tertinggi dalam keluarga pekerja wanita di Kota Jambi adalah sebanyak 5 orang tanggungan keluarga, sementara yang terendah adalah 0 atau tidak memiliki tanggungan keluarga. Untuk konsumsi rumah tangga pekerja wanita, total konsumsi terbesar yang dihabiskan oleh rumah tangga pekerja wanita untuk konsumsi pangan adalah sebesar Rp 2.328.000 dan yang paling terkecil adalah sebesar $\mathrm{Rp}$ 1.117.000 sehingga rata-rata konsumsi pangan rumah tangga pekerja wanita adalah sebesar Rp 1.720.333, sementara untuk konsumsi non pangan tertinggi yang dikeluarkan oleh rumah tangga pekerja wanita adalah sebesar $\mathrm{Rp}$ 7.915.000 sementara yang terendah adalah sebesar Rp 1.970.000 sehingga rata-rata konsumsi non pangan rumah tangga pekerja wanita di Kota Jambi adalah sebesar Rp 5.604.242.

\section{Gambaran Pola Konsumsi Pangan dan Non Pangan Rumah Tangga Pekerja Wanita di Kota Jambi}

Konsumsi rumah tangga adalah keseluruhan konsumsi rutin yang dikeluarkan oleh suatu rumah tangga yang digunakan untuk memenuhi kebutuhan pangan dan non pangan. Dalam penelitian ini, pengelompokkan konsumsi pangan dibagi ke dalam beberapa komoditas, seperti: 1) komoditas padi-padian, 2) komoditas ikan dan daging, 3) komoditas sayur-sayuran dan buah-buahan, 4) komoditas minyak dan kelapa, dan 5) komoditas makanan/minuman jadi. Sementara untuk konsumsi non pangan dikelompokkan ke dalam beberapa komoditas, seperti: 1) komoditas perumahan dan fasilitas rumah tangga, 2) komoditas kendaraan bermotor, 3) komoditas aneka barang dan jasa, 4) komoditas pajak, pungutan dan asuransi, dan 5) lainnya. Berikut ini pola konsumsi rumah tangga pekerja wanita di Kota Jambi yang dibedakan antara konsumsi pangan dan konsumsi non pangan: 
Tabel 1.3 Pola konsumsi pangan rumah tangga pekerja wanita di Kota Jambi

\begin{tabular}{|c|c|c|c|c|}
\hline \multicolumn{2}{|l|}{ Pangan } & Total & \multirow{2}{*}{$\begin{array}{r}\% \\
12 \\
\end{array}$} & \multirow{2}{*}{$\begin{array}{c}\begin{array}{c}\% \\
\text { Total }\end{array} \\
12 \\
\end{array}$} \\
\hline Komoditas padi-padian & Beras & Rp 24.073 .000 & & \\
\hline \multirow{3}{*}{ Komoditas ikan dan daging } & Ayam & Rp 41.873 .000 & 20 & \multirow{3}{*}{50} \\
\hline & Daging sapi & Rp $\quad 7.582 .000$ & 4 & \\
\hline & $\begin{array}{l}\text { Ikan } \\
\text { Jumlah }\end{array}$ & $\begin{array}{ll}\operatorname{Rp} & 53.584 .000 \\
\boldsymbol{R p} & \mathbf{1 0 3 . 0 3 9 . 0 0 0}\end{array}$ & 26 & \\
\hline $\begin{array}{l}\text { Komoditas sayur-sayuran } \\
\text { dan buah-buahan }\end{array}$ & Sayur \& buah & Rp 59.323 .000 & 29 & 29 \\
\hline Komoditas minyak dan kelapa & Minyak goreng & $\mathrm{Rp} \quad 5.308 .000$ & 3 & 3 \\
\hline $\begin{array}{l}\text { Komoditas makanan atau } \\
\text { minuman jadi }\end{array}$ & Galon & Rp 14.697 .000 & 7 & 7 \\
\hline Total Konsumsi & p 206.440.000 & & & 100,00 \\
\hline
\end{tabular}

Sumber: Diolah dari Data Primer 2019

Berdasarkan Tabel 1.3 menunjukkan bahwa konsumsi pangan rumah tangga pekerja wanita di Kota Jambi yang terbesar berada pada komoditas ikan dan daging dimana komoditas ini dibagi lagi menjadi kelompok ayam sebesar Rp 41.873.000, daging sapi sebesar Rp 7.582.000 dan ikan sebesar Rp 53.584.000 atau jika dinyatakan dalam persentase sebesar $50 \%$. Sementara untuk konsumsi kedua terbesar terletak pada komoditas sayur-sayuran dan buah-buahan dengan total konsumsi sebesar Rp 59.323.000 atau 29\%. Konsumsi ketiga terbesar berada pada komoditas padi-padian dimana yang termasuk dalam komoditas ini adalah kelompok beras yang merupakan makanan pokok setiap rumah tangga pekerja wanita di Kota Jambi dengan total konsumsi sebesar Rp 24.073.000 atau jika dinyatakan dalam persentase sebesar $12 \%$. Selanjutnya, konsumsi keempat terbesar berada pada komoditas makanan atau minuman jadi dimana yang termasuk dalam komoditas ini adalah kelompok galon dengan total konsumsi sebesar Rp 14.697.000 atau jika dinyatakan dalam persentase sebesar 7\%. Sementara konsumsi pangan rumah tangga pekerja wanita paling kecil berasal dari komoditas minyak dan kelapa dimana yang termasuk dalam komoditas ini adalah kelompok minyak goreng dengan total konsumsi sebesar Rp 5.308.000 atau jika dinyatakan dalam persentase sebesar 3\%. Melalui Tabel 1.3 ini dapat dilihat bahwa total konsumsi pangan rumah tangga pekerja wanita di Kota Jambi adalah sebesar Rp 206.440.000. 
Tabel 1.4 Pola konsumsi non pangan rumah tangga pekerja wanita di Kota Jambi

\begin{tabular}{|c|c|c|c|c|}
\hline \multicolumn{2}{|c|}{ Non Pangan } & Total & $\%$ & $\begin{array}{c}\% \\
\text { Total }\end{array}$ \\
\hline \multirow{3}{*}{$\begin{array}{l}\text { Komoditas perumahan } \\
\text { dan fasilitas rumah } \\
\text { tangga }\end{array}$} & Sewa air & Rp 22.191.000 & 3 & \multirow{3}{*}{13} \\
\hline & Listrik & $\mathrm{Rp} \quad 68.104 .000$ & 10 & \\
\hline & Jumlah & $R p$ 90.295.000 & & \\
\hline \multirow{3}{*}{$\begin{array}{l}\text { Komoditas kendaraan } \\
\text { bermotor }\end{array}$} & Transportasi & Rp 77.004.000 & 11 & \multirow{3}{*}{13} \\
\hline & Elpiji/LPG & $\operatorname{Rp} \quad 14.166 .000$ & 2 & \\
\hline & Jumlah & $R p \quad 91.170 .000$ & & \\
\hline $\begin{array}{l}\text { Komoditas aneka } \\
\text { barang dan jasa }\end{array}$ & $\begin{array}{l}\text { Biaya } \\
\text { Pendidikan }\end{array}$ & $\operatorname{Rp} 262.705 .000$ & 39 & 39 \\
\hline $\begin{array}{l}\text { Komoditas pajak, } \\
\text { pungutan dan asuransi }\end{array}$ & Biaya Kesehatan & Rp 11.528 .000 & 2 & 2 \\
\hline Lainnya & $\begin{array}{l}\text { Bepergian/ } \\
\text { rekreasi }\end{array}$ & $\operatorname{Rp} 216.811 .000$ & 32 & 32 \\
\hline \multicolumn{2}{|c|}{ Total Konsumsi } & \multicolumn{2}{|l|}{ Rp 672.509.000 } & 100,00 \\
\hline
\end{tabular}

Sumber: Diolah dari Data Primer 2019

Berdasarkan Tabel 1.4 menunjukkan bahwa konsumsi non pangan rumah tangga pekerja wanita di Kota Jambi yang terbesar berada pada komoditas aneka barang dan jasa dimana yang termasuk dalam komoditas ini adalah biaya yang dikeluarkan untuk biaya pendidikan dengan total konsumsi sebesar Rp 262.705.000 atau 39\%. Sementara untuk konsumsi kedua terbesar terletak pada komoditas lainnya dimana yang termasuk dalam komoditas ini adalah biaya yang dikeluarkan untuk biaya bepergian/rekreasi (bisa sekadar pergi ke mall) dengan total konsumsi sebesar Rp 216.811 .000 atau $32 \%$. Konsumsi ketiga terbesar berada pada komoditas perumahan dan fasilitas rumah tangga (meliputi biaya untuk sewa air dan listrik) dan komoditas kendaraan bermotor (meliputi biaya untuk transportasi dan elpiji/LPG) dengan total konsumsi masing-masing sebesar Rp 90.295.000 dan Rp 91.170.000 yang jika dinyatakan dalam persentase adalah masing-masing sebesar $13 \%$. Selanjutnya konsumsi non pangan rumah tangga pekerja wanita di Kota Jambi terkecil berasal dari komoditas pajak, pungutan dan asuransi dimana yang termasuk dalam komoditas ini adalah biaya yang dikeluarkan untuk biaya kesehatan dengan total konsumsi sebesar Rp 11.528.000 atau jika dinyatakan dalam persentase sebesar 2\%. Melalui Tabel 1.4 ini dapat dilihat bahwa total konsumsi non pangan rumah tangga pekerja wanita di Kota Jambi adalah sebesar Rp 672.509.000.

\section{Analisis Faktor-Faktor Yang Mempengaruhi Konsumsi Rumah Tangga Pekerja Wanita di Kota Jambi}

\section{Uji Asumsi Klasik}

Uji Normalitas

Uji yang dilakukan untuk melihat apakah nilai residual terdistribusi normal atau tidak adalah dengan melakukan uji normalitas, salah satunya dengan menggunakan konsep Jorque-Berra Test, yaitu sebagai berikut: 
Gambar 1.1 Hasil pengujian normalitas

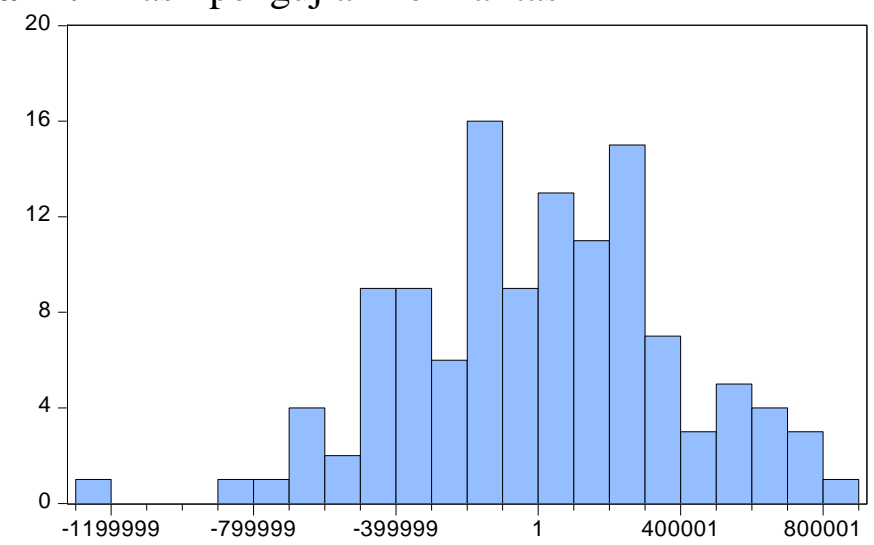

Sumber: Output Eviews9 Data diolah 2019

\begin{tabular}{|lr|}
\hline \multicolumn{2}{|l|}{ Series: Residuals } \\
Sample 1 120 \\
Observations 120 \\
Mean & $-1.07 e-09$ \\
Median & 25347.41 \\
Maximum & 854805.8 \\
Minimum & -1208833. \\
Std. Dev. & 374608.8 \\
Skewness & -0.155550 \\
Kurtosis & 3.087739 \\
& \\
Jarque-Bera & 0.522405 \\
Probability & 0.770125 \\
\hline
\end{tabular}

Melalui Gambar 1.1 diketahui bahwa nilai probabilita J-B hitung 0,770125 lebih besar dari nilai probabilita $\alpha(0,05)$ dalam pendekatan Jarque-Berra test, maka maka model di atas berdistribusi normal dan terbebas dari gejala normalitas.

\section{Uji Multikolinearitas}

Uji multikolinieritas adalah uji yang dilakukan untuk memastikan apakah di dalam sebuah model regresi ada interkorelasi atau kolinieritas antar variabel bebas di mana dalam penelitian ini yang termasuk dalam variabel bebas adalah pendapatan istri, pendapatan suami, pendidikan dan jumlah tanggungan keluarga. Salah satu cara untuk mendeteksi adanya multikolinieritas adalah dengan melihat nilai Variance Inflation Factor (VIF), yaitu sebagai berikut:

Gambar 1.2 Hasil pengujian multikolinearitas

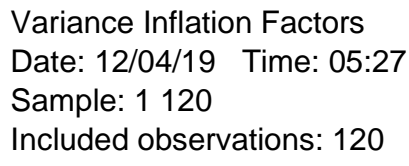

\begin{tabular}{cccc}
\hline \hline Variable & $\begin{array}{c}\text { Coefficient } \\
\text { Variance }\end{array}$ & $\begin{array}{c}\text { Uncentered } \\
\text { VIF }\end{array}$ & $\begin{array}{c}\text { Centered } \\
\text { VIF }\end{array}$ \\
\hline \hline C & $4.01 \mathrm{E}+11$ & 331.5440 & NA \\
PI & 0.004339 & 87.96140 & 1.362571 \\
PS & 0.000780 & 13.48777 & 1.163627 \\
PDD & $1.96 \mathrm{E}+09$ & 405.6530 & 1.241431 \\
JTK & $1.29 \mathrm{E}+09$ & 7.801350 & 1.292182 \\
\hline \hline
\end{tabular}

Sumber: Output Eviews9 Data diolah 2019

Berdasarkan Gambar 1.2 dapat dilihat nilai Variance Inflation Factor (VIF) variabel pendapatan istri, pendapatan suami, pendidikan dan jumlah tanggungan keluarga terhadapan konsumsi rumah tangga pekerja wanita di Kota Jambi kurang dari 10 maka dapat dinyatakan bahwa tidak terdapat gejala multikolinieritas dalam model regresi ini. 


\section{Uji Heteroskedastisitas}

Uji heteroskedastisitas adalah sebuah uji untukmelihat apakah terdapat ketidaksamaan varians dari residual satu ke pengamatan yang lain.Hasil uji heteroskedastisitas dapat dilihat sebagai berikut:

Gambar 1.3 Hasil pengujian heteroskedastisitas

Heteroskedasticity Test: White

\begin{tabular}{llll}
\hline \hline F-statistic & 0.782268 & Prob. F(4,115) & 0.5389 \\
Obs*R-squared & 3.178631 & Prob. Chi-Square(4) & 0.5284 \\
Scaled explained SS & 3.047330 & Prob. Chi-Square(4) & 0.5499 \\
\hline \hline
\end{tabular}

Sumber: Output Eviews9 Data diolah 2019

Berdasarkan Gambar 1.3 dapat diketahui bahwa nilai p-value Obs*R-Squared sebesar $0,5284>0,05$ maka dinyatakan model ini terbebas dari masalah heteroskedastisitas.

\section{Model Regresi}

Berikut adalah hasil dari analisis regresi linier berganda yang diolah dengan menggunakan Eviews9 dengan tingkat signifikansi sebesar $\alpha=5 \%$.

Tabel 1.2 Hasil estimasi faktor-faktor yang mempengaruhi konsumsi rumah tangga pekerja wanita di Kota Jambi

\begin{tabular}{crrrr}
\hline \multicolumn{1}{c}{ Variable } & Coefficient & Std. Error & t-Statistic & Prob. \\
\hline C & -344475.6 & 633406.5 & -0.543846 & 0.5876 \\
PI & 0.813723 & 0.065869 & 12.35374 & 0.0000 \\
PS & 0.767725 & 0.027937 & 27.48079 & 0.0000 \\
PDD & -5933.686 & 44219.85 & -0.134186 & 0.8935 \\
JTK & 164769.1 & 35859.11 & 4.594904 & 0.0000 \\
R-squared & 0.917542 & Mean dependent var & 7324575. \\
Adjusted R-squared & 0.914674 & S.D. dependent var & 1304555. \\
S.E. of regression & 381068.0 & Akaike info criterion & 28.58012 \\
Sum squared resid & $1.67 E+13$ & Schwarz criterion & 28.69626 \\
Log likelihood & -1709.807 & Hannan-Quinn criter. & 28.62728 \\
F-statistic & 319.9136 & Durbin-Watson stat & 1.782899 \\
Prob(F-statistic) & 0.000000 & & & \\
\hline
\end{tabular}

Sumber: Data diolah, 2019

Berdasarkan tabel di atas, maka diperoleh persamaan regresi sebagai berikut:

$\mathrm{Y}=-344475.6+0.813723$ PI + 0.767725 PS - 5933.686 PDD + 164769.1 JTK

\section{Pengujian Hipotesis}

\section{Analisis Determinasi $\left(R^{2}\right)$}

Dari hasil penelitian diperoleh R-squared sebesar 0.917542 atau 91,75\% sehingga dapat dinyatakan memiliki korelasi keeratan yang cukup kuat terhadap konsumsi rumah tangga pekerja wanita di Kota Jambi. Hal ini menjelaskan bahwa variabel pendapatan istri, pendapatan suami, pendidikan dan jumlah tanggungan keluarga mempengaruhi konsumsi rumah tangga pekerja wanita di Kota Jambi sebesar 
$91,75 \%$ sementara sisanya $8,25 \%$ dipengaruhi oleh variabel lainnya yang tidak dimasukkan ke dalam penelitian ini.

\section{Uji Statistik F}

Uji statistik $\mathrm{F}$ dilakukan dengan tujuan untuk mengetahui apakah variabel independen secara bersama-sama berpengaruh signifikan terhadap variabel dependen yaitu dengan cara melihat signifikan $\alpha=5 \%$. Berdasarkan Tabel 1.2 dapat kita lihat bahwa nilai $F$ hitung sebesar 319.9136 dengan probabilita sebesar $(0.000000)$ atau lebih kecil dari $\alpha=0.05(0.000000<0.05)$ artinya Ho ditolak dan Ha diterima pada tingkat keyakinan $95 \%$ sehingga dapat disimpulkan bahwa variabel pendapatan istri, pendapatan suami, pendidikan dan jumlah tanggungan keluarga berpengaruh secara bersama-sama terhadap konsumsi rumah tangga pekerja wanita di Kota Jambi.

\section{Uji Statistik $\mathbf{t}$}

Faktor-faktor yang mempengaruhi konsumsi rumah tangga pekerja wanita di Kota Jambi adalah pendapatan istri, pendapatan suami, pendidikan dan jumlah tanggungan keluarga. Melalui Tabel 5.11 dapat dijelaskan pengujian koefisien regresi pendapatan istri, dapat dilihat t hitung sebesar 12.35374 dengan probabilita sebesar 0.0000 atau lebih kecil dari $\alpha=5 \%(0.0000<0.05)$ yang artinya Ho ditolak dan Ha diterima. Dari hasil tersebut dapat disimpulkan bahwa variabel pendapatan istri berpengaruh secara parsial dan signifikan terhadap konsumsi rumah tangga pekerja wanita di Kota Jambi.

Koefisien regresi variabel pendapatan suami, dapat dilihat bahwa nilai t hitung sebesar 27.48079 dengan probabilita sebesar 0.0000 atau lebih kecil dari $\alpha=5 \%$ $(0.0000<0.05)$ yang artinya Ho ditolak dan Ha diterima. Dari hasil tersebut dapat disimpulkan bahwa variabel pendapatan suami berpengaruh secara parsial dan signifikan terhadap konsumsi rumah tangga pekerja wanita di Kota Jambi.

Koefisien regresi variabel pendidikan, dapat dilihat bahwa nilai t hitung sebesar -0.134186 dengan probabilita sebesar 0.8935 atau lebih besar dari $\alpha=5 \%(0.8935>$ 0.05) yang artinya Ho diterima dan Ha ditolak. Dari hasil tersebut dapat disimpulkan bahwa variabel pendidikan memiliki pengaruh yang tidak signifikan terhadap konsumsi rumah tangga pekerja wanita di Kota Jambi.

Koefisien regresi variabel jumlah tanggungan keluarga (JTK), dapat dilihat bahwa nilai t hitung sebesar 4.594904 dengan probabilita sebesar 0.0000 atau lebih kecil dari $\alpha=5 \%(0.0000<0.05)$ yang artinya Ho ditolak dan Ha diterima. Dari hasil tersebut dapat disimpulkan bahwa variabel jumlah tanggungan keluarga berpengaruh secara parsial dan signifikan terhadap konsumsi rumah tangga pekerja wanita di Kota Jambi.

\section{KESIMPULAN DAN SARAN}

\section{Kesimpulan}

Pekerja wanita di Kota Jambi paling banyak berasal dari kelompok umur 30 - 34 dan paling banyak berasal dari suku Jawa sementara suaminya paling banyak berasal dari suku Minang. Sebagian besar pekerja wanita di Kota Jambi telah menempuh jenjang pendidikan S1 dengan rata-rata pendapatan yang diterima setiap bulannya sebesar Rp 4.914.617, sementara pendapatan yang terima oleh suami setiap bulannya rata-rata sebesar $\mathrm{Rp}$ 4.371.333. Jumlah tanggungan keluarga terbanyak berada pada kelompok tanggungan keluarga sebanyak 5 (lima) orang dan terkecil berada pada pada 
kelompok tanggungan keluarga sebanyak 0 (nol) atau tidak memiliki tanggungan keluarga, sehingga rata-rata jumlah tanggungan keluarga yaitu \pm 2 orang tanggungan keluarga. Konsumsi pangan rumah tangga pekerja wanita di Kota Jambi yang terbesar berada pada komoditas ikan dan daging di mana komoditas ini dibagi lagi menjadi kelompok ayam, daging sapi dan ikan dengan total konsumsi sebesar Rp 86.139.000 atau 44\%. Sementara untuk konsumsi kedua terbesar terletak pada komoditas sayursayuran dan buah-buahan dengan total konsumsi sebesar Rp 103.039 .000 atau 50\%. Sementara untuk konsumsi non pangan rumah tangga pekerja wanita di Kota Jambi yang terbesar berada pada komoditas aneka barang dan jasa di mana yang termasuk dalam komoditas ini adalah biaya yang dikeluarkan untuk biaya pendidikan dengan total konsumsi sebesar Rp 262.705.000 atau 39\% lalu konsumsi kedua terbesar terletak pada komoditas lainnya di mana yang termasuk dalam komoditas ini adalah biaya yang dikeluarkan untuk biaya bepergian/rekreasi (bisa sekadar pergi ke mall) dengan total konsumsi sebesar $\mathrm{Rp} 216.811 .000$ atau 32\%. Berdasarkan hasil analisis dengan menggunakan regresi linier berganda untuk melihat faktor-faktor yang mempengaruhi konsumsi rumah tangga pekerja wanita, maka diperoleh hasil bahwa variabel pendapatan istri, pendapatan suami, pendidikan dan jumlah tanggungan keluarga secara bersama-sama mempengaruhi konsumsi rumah tangga pekerja wanita di Kota Jambi. Sementara itu, secara parsial variabel pendapatan istri, pendapatan suami dan jumlah tanggungan keluarga memiliki pengaruh yang signifikan terhadap konsumsi rumah tangga pekerja wanita di Kota Jambi sementara variabel pendidikan tidak berpengaruh signifikan terhadap konsumsi rumah tangga pekerja wanita di Kota Jambi.

\section{Saran}

Penelitian ini diharapkan mampu memberikan tambahan informasi dan pengetahuan mahasiswa dalam pengembangan ilmu pengetahuan dan teori yang telah diperoleh terutama teori konsumsi. Hasil penelitian ini juga dapat digunakan sebagai dasar penelitian lanjutan yang serupa dengan penelitian ini. Kemudian, sudah seharusnya pola konsumsi harus disesuaikan dengan pendapatan yang diperoleh oleh suatu rumah tangga dan tidak ada yang salah dengan para ibu rumah tangga yang juga turun ke pasar kerja karena dengan partisipasi yang diberikan dapat memberi tambahan untuk pendapatan rumah tangga.

\section{DAFTAR PUSTAKA}

Badan Pusat Statistik Provinsi Jambi. (2017). Analisis Pola Konsumsi Masyarakat Provinsi Jambi Maret 2017. Badan Pusat Statistik Provinsi Jambi.

Badan Pusat Statistik Provinsi Jambi. (2017). Analisis Situasi Ketenagakerjaan Provinsi Jambi 2017. BPS: Provinsi Jambi.

Badan Pusat Statistik Provinsi Jambi. (2017). Tingkat Partisipasi Angkatan kerja (TPAK) menurut Kabupaten/Kota, 2007- 2017. BPS: Provinsi Jambi.

Indrayati, Ariani. 2010. Peran Wanita Dalam Pemerdayaan Ekonomi Lokal (Studi Kasus Tentang Pola Ruang Belanja Wanita di Daerah Pinggiran Kota Semarang). Jurnal Gografis, 7(2), 88-102.

Jhingan, M.L., (2016). Ekonomi Pembangunan dan Perencanaan. Jakarta: Rajawali Pers.

Kotler, P. (2005). Manajemen Pemasaran Edisi Milenium Jilid 1 Terjemahan Benjamin Molan. Jakarta: Prenhallindo. 
Lestari, Yuliana Intan. 2017. Fear of Success Pada Perempuan Bekerja Ditinjau Dari Konflik Peran Ganda dan Hardiness.Jurnal Psikologi 13(1), 55-63.

Mangkunegara, A.A. Anwar. (2005). Perilaku Konsumen. Bandung: PT Refika Aditama.

McKinsey Global Institute. 2012. The Archipelago Economy: Unleashing Indonesia's Potential. Jakarta: McKinsey Global Institute.

Nofianti, Leny. 2016. Perempuan di Sektor Publik.Jurnal Perempuan, Agama dan Jender 15(1), 51-61.

Setiadi, Nugroho J. (2003). Perilaku Konsumen. Jakarta: Kencana.

Sitorus, Agnes Vera Yanti. 2016. The Impact Of Gender Inequality On Economic Growth In Indonesia. Jurnal Sosio Informa 2(1), 89-101.

Stalker, Peter. 2008. Millenium Development Goals. http://www.id.undp.org/content/indonesia/en/home/search.html?q=millenium+d evelopment.Diakses pada tanggal 27 Maret 2019. 